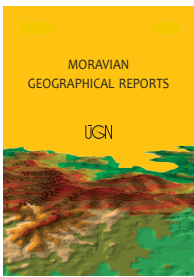

MORAVIAN GEOGRAPHICAL REPORTS

\title{
Are there differences in the attractiveness of shopping centres? Experiences from the Czech and Slovak Republics
}

\author{
Josef KUNC ${ }^{\text {a * }}$, František KRIŽAN ${ }^{\text {b }}$, Kristína BILKOVÁ ${ }^{\mathrm{b}}$, Peter BARLÍK ${ }^{\mathrm{b}}$, Jaroslav MARYÁŠ a
}

\begin{abstract}
The measurement and evaluation of the attractiveness of shopping centres in the Czech and the Slovak Republics is examined in this paper, countries which had experienced seventy years of development within a single state. The methodological basis for measuring the attractiveness of 130 shopping centres is an evaluation of the factors that can be described as objective (exogenous and endogenous) and subjective (in vivo and in vitro approach). An aggregate indicator of the overall attractiveness of each shopping centre was computed as a combination of the sub-variables. Based on previous international studies, the factors (variables influencing attractiveness) that are typical for shopping malls anywhere in the world, as well as for the original specific information for the Czech-Slovak retail environment, enable a generalization of the results at least to the East Central European level, and to carry out a comparison with any other market environment.
\end{abstract}

Keywords: shopping centres, attractiveness, similarities and differences, Czech Republic, Slovak Republic

Article history: Received 4 May 2015; Accepted 29 January 2016; Published 31 March 2016

\section{Introduction}

The phenomenon of shopping centres ${ }^{1}$ is probably the most significant manifestation of current retail business in both the Czech and the Slovak Republic. We mean not only the frequently hard-to-overlook physical appearance, but especially the social and cultural phenomena of shopping centres, which has modified long-established patterns of (not only) shopping behaviours and shopping customs of the majority of the population (Grosmanová et al., 2015; Križan, 2009; Križan et al., 2014; Kita and Grosmanová, 2014; Kunc et al., 2013; Spilková, 2012a, 2012b; Timothy, 2005).

The main role of retailing, the sales of goods and services to final consumers, has been transforming into its contemporary format for several decades. Continually accelerating globalisation and internationalisation trends are reflected in hurried and hectic ways of life and lack of time (Giddens, 2002). The new dimensions of large-area chain stores and shopping centres have not only pushed the formerly traditional forms of retail shopping out of the attention of shoppers (Szczyrba, 2005), but shopping centres have replaced to a large extent traditional public spaces with everything that belongs in them (Cooper, 2007; Jackson et al., 2011; van Leeuwen, Rietveld, 2011; Voyce, 2006). Many commercial and non-commercial functions (e.g. catering, post offices, banks, medical offices, etc.) have gradually "moved over" from individual municipal districts to the shopping centres. As indicated by Spilková and Hochel' (2009) and Pospěch (2010), shopping centres became one of the key bearers of changes in the consumer societies of post-socialist countries.

If we follow the relationship between shopping and place of purchase, we find that it does not always have to serve the economic reasons of the rational consumer. This disproves the previously-accepted opinions that a consumer prefers minimal mobility for shopping and behaves entirely economically, as indicated in the earlier previous research by Rushton (1969) and Potter (1979). Later work showed that the consumers choose their place of purchases according to other factors, e.g. choice of goods, good service, services,

\footnotetext{
${ }^{a}$ Department of Regional Economics and Administration, Faculty of Economics and Administration, Masaryk University, Brno, Czech Republic (*corresponding author: Josef Kunc, e-mail: kunc@econ.muni.cz)

b Department of Regional Geography, Protection and Planning of the Landscape, Faculty of Natural Sciences, Comenius University in Bratislava, Bratislava, Slovak Republic
}

\footnotetext{
${ }^{1}$ To find uniform criteria for the classification of shopping centres remains difficult; we will use the methodological approach of the European classification of ICSC (2005), i.e., with respect to Cushman \& Wakefield (2011), with a gross leasable area of 5,000 $\mathrm{m}^{2}$. In the Czech Republic, this database represents 83 shopping centres and in the Slovak Republic, 47.
} 
size, cleanliness, atmosphere, shops, and the level of the attractiveness of a shopping place. Experience shows that people often do not respect the logic of economic thinking and they do not follow strictly economic aspects. As reported by Walmsley and Lewis (1984), if a large modern business centre, offering high-quality services, a wide range of goods, good prices, etc. was built in a certain town, not all people around would do their shopping in it. On the contrary, it would be possible to observe shoppers from relatively longdistance locations. It turns out that shopping is influenced by many factors varying in time and space, and that it is a relatively complicated social phenomenon.

Thus, consumer behaviours cannot be simplified and summarized in some general model. They are continually shaped by the influences of specific changes in the retail sector and in retail networks. Golledge and Stimson (1997) and Spilková (2003) describe the formation of the process of shopping behaviour in economies of transformation as a transition between the phases of the organisation of society and the economy, i.e. the transition from socialism through a transitional phase to the market economies. Shopping behaviour is not just a repeating unchanging activity, but it is going through processes of forming. A consumer goes through the process of space searching, before collecting the necessary information about retail opportunities, so that $\mathrm{s}$ / he can subsequently exclude those that are unfavourable unattractive ones.

Modern malls became "worlds in themselves" (Crawford, 1992), comprised of shopping services as well as social and cultural activities (Kunc et al., 2012a, 2012c), and people like to "gravitate" (Wolf, 2003) towards these "magnets". The objective of this paper is to measure the attractiveness of the shopping centres in the Czech Republic and Slovakia, with an emphasis on exogenous (localization) and endogenous (operation and assortment) factors, and a summary (subjective) measure of centre attractiveness for potential visitors. The methodological approach is based on numerous examples of similar empirical studies dealing with the different ways of measuring the attractiveness of shopping centres. On the other hand, the specifics of the Czech-Slovak retail environment introduce an original element to the study of attractiveness. The data and information on the two case study countries are not bounded determinants, but they are shifting the results to implications and generalisation. Moreover, the variables used (factors determining attractiveness) are so typical of studies of most shopping centres in the world that they cannot be completely avoided in similar analyses. Thus the results of the study can be used for broader comparisons beyond the limits of East Central Europe.

In the first place, this contribution is trying to answer the following questions:

- Q1: Is the attractiveness of shopping centres similar in the Czech and Slovak Republics? Is this the case in terms of the character of the countries and consumer behaviours resulting from the cultural and historical contexts of East Central Europe?;

- Q2: In general, is the attractiveness of the shopping centres linked to the size of the city, its institutional position (state capitals versus regional centres), and location "inside" the city?; and

- Q3: What is the impact of endogenous and exogenous factors, as well as the subjective factors, on the aggregate aspect of attractiveness?
This paper is divided into four sections. After the theoretical introduction, the phenomenon of shopping centres in the Czech and Slovak Republics is discussed. The methods and data used in the analysis are then discussed, followed by the results in terms of the existing literature. After the conclusions, some major limitations of the empirical study and ideas for future research are discussed.

\section{The attractiveness of shopping centres}

Shopping centres or retail outlets generally compete with each other for customers. They are trying to attract clients with a range of shops and services, entertainment and various events, as well as new channels of sales and place marketing (Teller and Elms, 2012; Warnaby et al., 2005). As claimed by Finn and Louviere (1996, p. 241), most research that has collected image ratings data for shopping centres has studied a limited number of centres and analysed the dimensionality of the image data across consumers. But, from a management perspective, it is not clear why shopping centre managers would be concerned about the dimensionality of image (in this case attractiveness) when the analysis is conducted using a sample of consumers. From a manager's perspective, it may be more important to identify centre characteristics that determine the image of the shopping centres in their market. Teller et al. (2015) see the managers as key to unlocking potential and consequently building up a competitive advantage for the network and its nodes. More specifically, a manager's willingness and ability to collaborate and thereby cross boundaries to other stores (shopping centres) is the important factor.

All of these as well as other characteristics of retail create its attractiveness. Therefore, the issue of the attractiveness of shopping centres has gained the attention of the academic community as well as practice in recent years, as evidenced by the number of expert studies (e.g. Arentz and Timmermans 2001; Awang et al., 2013; Burns and Warren, 1995; Dębek, 2015; Guy, 1998; Lusch and Serpkenci, 1990; Teller and Alexander, 2014; Teller and Reutterer, 2008; Teller and Elms, 2010)

The attractiveness of shopping centres is influenced by many characteristics, which can be divided into four groups (Teller and Reutterer, 2008): i) site-related factors; ii) tenant-related factors; iii) environment-related factors; and, iv) the buying situation-related factors. These groups of factors include a wide variety of more specific factors (Dębek, 2015; Micu, 2013; Teller, 2008; Teller and Elms, 2010, 2012, and others).

The factors of "accessibility" and "parking" are important in the group of site-related factors. In general, we can say that the attractiveness of a shopping centre decreases with distance (accessibility) to the centre (Dennis et al., 2002a). Retail agglomerations are attractive for consumers because they reduce the cost and time of travel, as the closer they are, the fewer trips are required (Ghosh, 1986). Research has shown that larger shopping centres offering free car parking are often perceived as more attractive than traditional town centres (Timmermans, 1996; Teller and Reutterer, 2008). Moreover, the availability of public transportation near to shopping centres may influence the choice of place of purchase (Ibrahim and McGoldrick, 2003). The parking possibilities also influence the comfort of purchase (Alzubaidi et al., 1997). A study by Marjanen (1995) points out that parking facilities, a large shopping area and the availability of more diversified goods influence shopping. On 
the other hand, the significance of the factor of parking has been discussed, as some studies question the impact of this factor on retail turnover (cf. Mingardo and Meerkerk, 2012; van der Waerden, 1998).

The second tenant-related group involves two groups of factors (Teller and Reutterer, 2008). The first group of factors represents "mix of retail-tenants" and the second "mix of non-retail tenants", such as gastronomy and entertainment facilities (bars, restaurants or cinemas) (Garg and Steyn, 2014; Wakefield and Baker, 1998). Tenant mix (retail and non-retail) affects the success of the mall, because a proper tenant mix can attract more patrons and thus increase the sales of retailers (Abrate et al., 1985). On the other hand, it should be noted that an appropriately selected tenant mix can cause some synergistic effects (Mejia and Epple, 1999). It can also be due to the fact that "anchor stores" attract the highest or a higher share of customers in comparison with other smaller retail tenants (Levy and Weitz, 2006). As claimed by Bean et al. (1988), the concept of an ideal tenant mix has not yet been formulated, which provides reasons for further research in this area (Garg and Steyn, 2014; Plăiaş and Abrudan, 2013). Generally, this group of factors is considered to be that with the highest relative importance (Teller, 2008)

The environment-related factors in the third group include factors such as "orientation" and "ambience" (Teller and Reutterer, 2008), but mainly "atmosphere" (Wakefield and Baker, 1998). Atmosphere is the first and sometimes the most important factor affecting the attractiveness of a shopping centre (cf. Turley and Milliman, 2000). As Teller et al. (2010) noted, the retail tenant mix and the atmosphere are the most important influencing factors. More specifically, the effects of retail tenant mix are strongest where there is a direct influence on the three endogenous factors. Atmosphere has a direct effect on satisfaction and retention proneness, with patronage intention being only indirectly affected. On the other hand, it should be noted that analysis of the attractiveness in terms of atmosphere is not clearly given, since the research concepts are diverse (Dębek, 2015).

The last group of factors is represented by the buying situation-related factors. This is a subjective factor evaluated from an individual's point of view and includes two factors (Teller and Reutterer, 2008): the perceived 'distance' between the starting point of a specific trip and the destination of choice; and the perceived importance of a shopping trip, measured in terms of an individual's 'involvement'.

The attractiveness of a shopping centre can be measured by various methods, normally thought of as two approaches. The first of them utilizes primarily quantitative methods based on interaction models (Reilly, 1931, Huff, 1963). In the field of retail marketing, studies evaluating the attractiveness of retail locations have been classified by Teller (2008) in the following research streams:

1. approaches based on spatial interaction theory;

2. models of retail attraction based on random utility theory; and,

3. multiplicative competitive interaction models.

Such models refer to the establishment of "objective" criteria for attractiveness in terms of retail consumer perceptions. The second group is represented by methods evaluating the attractiveness to consumers primarily by applying more qualitative methodologies such as interviews and questionnaires, in particular in-home interviews or telephone surveys (Teller and Reutterer, 2008). While the first group of methods has a dominantly spatial character in an effort to determine the boundaries of the impact of retail units, the second group has a socio-economic nature in order to tackle place marketing.

\section{Methods and data}

Evaluation of the attractiveness of shopping centres is based on the preferences of consumers as the main factor determining attractiveness in many studies (McGoldrick and Thompson, 1992; Oppewal et al., 2006; Teller, 2008). Retail attraction research can be categorized as two approaches (Teller and Reutterer, 2008). The first of them, "in vitro", uses interviews or telephone surveys, which requires strong imaginary skills (particularly with regard to unfamiliar retail sites) and/or the high shopping involvement of respondents. The second approach can be called by analogy "in vivo", as it requires the analyst to confront respondents with more realistic shopping tasks or even real shopping situations. The evaluation of the preferences of a representative sample of respondents can be considered particularly demanding in order to analyse the 130 shopping centres in the two countries (Tab. 1). Therefore, we used a special case of the "in vitro" approach in this contribution.

In general, the attractiveness of shopping centres can be evaluated by the following variables: availability, number of parking places, size of leasable area, structure of retail stores, business hours, atmosphere/visual characteristics of the shopping centre, pricing, social events, etc. (Donovan and Rossiter, 1982; Nevin and Houston, 1980; Teller, 2008; Teller and Reutterer, 2008; Sit et al., 2003; Uschev et al., 2015; Wakefield and Baker, 1998). In this study, the attractiveness of the shopping centres was evaluated on the basis of the factors divided into three groups: A) exogenous; B) endogenous; and, C) complex factors (Tab. 2).

The factors under evaluation are articulated in various units of measure, which makes it impossible to compare them. Therefore we have standardised the quantified measures using Z-scores. Using this method, we have eliminated the dependence of the data on the units of measurement and on the location and variance parameters. These standardised data were subsequently individually assessed for each shopping centre according to the following formula:

$$
A M_{i}=\left(\sum A_{i 1}+A_{i 2}+A_{i 3}\right)+\left(\sum B_{i 1}+B_{i 2}+B_{i 3}\right)+\frac{\sum C_{i 1}}{n_{i}}
$$

where,

$A M_{i}$ is the measure of (aggregate) attractiveness for shopping centre $i ; A_{\text {in }}$ is an exogenous factor $n$ for shopping centre $i,(\mathrm{n}=1,2,3) ; B_{\text {in }}$ is an endogenous factor $n$ for shopping centre $i,(\mathrm{n}=1,2,3) ; C_{i 1}$ is a complex factor for shopping centre $I$, and $n_{i}$ is the number of evaluated factors for shopping centre $i$.

Similarly to the quantification of the complex factor C, the empirical estimation of 10 experts, both from the business and academic environments, was used to establish the aggregate measure of attractiveness AM ("in vitro" approach). The expert group was provided with data for all factors under assessment (A, B and C) and, according to the variable values, they independently and anonymously defined limits for five categories of shopping centre attractiveness: (1) very high; (2) moderately high; (3) average; (4) limited; and, (5) 


\begin{tabular}{|c|c|c|c|c|c|}
\hline \multicolumn{6}{|c|}{ Czech Republic } \\
\hline No. & Name & City & No. & Name & City \\
\hline 1 & Centrum Černý Most & Praha & 46 & OC Laso Ostrava & Ostrava \\
\hline 2 & Avion Shopping Park & Brno & 47 & OC Šestka & Praha \\
\hline 3 & Spektrum & Průhonice Čestlice & 48 & Obchodní centrum DBK & Praha \\
\hline 4 & NC Borská Pole & Plzeň & 49 & OC Novodvorská Plaza & Praha \\
\hline 5 & Avion Shopping Park & Praha & 50 & OZC Zlaté jablko & Zlín \\
\hline 6 & Nákupní centrum Průhonice & Říčany u Prahy & 51 & NC Géčko České Budějovice & České Budějovice \\
\hline 7 & Olympia Brno & Brno & 52 & OC Dragoun & Cheb \\
\hline 8 & OC Grand Pardubice & Pardubice & 53 & NC Géčko Liberec & Liberec \\
\hline 9 & OC Letňany & Praha & 54 & Bondy centrum & Mladá Boleslav \\
\hline 10 & GECO Ústí Všebořice & Ústí nad Labem & 55 & Plzeň Plaza & Plzeň \\
\hline 11 & OC Futurum & Hradec Králové & 56 & OC Galerie Dvořák & Plzeň \\
\hline 12 & OC Futurum & Ostrava & 57 & Palladium & Praha \\
\hline 13 & Cíl Praha & Praha & 58 & Campus Square & Brno \\
\hline 14 & Park Hostivař & Praha & 59 & City Park Jihlava & Jihlava \\
\hline 15 & Centro Zlín Malenovice & Zlín & 60 & NC Oaza Kladno & Kladno \\
\hline 16 & OC Futurum & Brno & 61 & OC Futurum Kolín & Kolín \\
\hline 17 & Velký Špalíček Brno & Brno & 62 & Nisa Center & Liberec \\
\hline 18 & Čtyři Dvory & České Budějovice & 63 & Central Most & Most \\
\hline 19 & Olympia Mladá Boleslav & Mladá Boleslav & 64 & Afi Palace Pardubice & Pardubice \\
\hline 20 & Avion Shopping Park & Ostrava & 65 & Galerie Fénix & Praha \\
\hline 21 & OC Nový Smíchov & Praha & 66 & Arkády Pankrác Praha & Praha \\
\hline 22 & EuroCenter Hradec Králové & Hradec Králové & 67 & OC Atrium & Hradec Králové \\
\hline 23 & OC Haná Olomouc & Olomouc & 68 & OC Rýnovka & Jablonec nad Nisou \\
\hline 24 & OC Plzeň & Plzeň & 69 & Galerie Liberec Plaza & Liberec \\
\hline 25 & Metropole Zličín & Praha & 70 & Forum Liberec + My Tesco & Liberec \\
\hline 26 & OC Europark & Praha & 71 & Forum Ústí nad Labem & Ústí nad Labem \\
\hline 27 & Olympia Teplice & Teplice & 72 & Chomutovka & Chomutov \\
\hline 28 & OC Fontána & Karlovy Vary & 73 & Galerie Harfa & Praha \\
\hline 29 & OC Karviná & Karviná & 74 & OC Galerie Moritz & Praha \\
\hline 30 & Palác Flóra & Praha & 75 & Breda \& Weinstein & Opava \\
\hline 31 & NC Královo Pole & Brno & 76 & OC Forum Nová Karolina & Ostrava \\
\hline 32 & IGY Centrum & České Budějovice & 77 & Galerie Šantovka & Olomouc \\
\hline 33 & Olympia Olomouc & Olomouc & 78 & Centrum Krakov & Praha \\
\hline 34 & OC Silesia & Opava & 79 & Fontána Teplice & Teplice \\
\hline 35 & Olympia Plzeň & Plzeň & 80 & Centrum Pivovar Děčín & Děčín \\
\hline 36 & Galerie Vaňkovka & Brno & 81 & OC Lužiny & Praha \\
\hline 37 & OC Cukrovar & Hodonín & 82 & Florentinum & Praha \\
\hline 38 & OC Varyáda & Karlovy Vary & 83 & Galerie Teplice & Teplice \\
\hline 39 & Olomouc City & Olomouc & & & \\
\hline 40 & OC Galerie & Ostrava & & & \\
\hline 41 & Galerie Butovice & Praha & & & \\
\hline 42 & Centrum Chodov & Praha & & & \\
\hline 43 & NC Eden & Praha & & & \\
\hline 44 & Centrum Zlín Čepkov & Zlín & & & \\
\hline 45 & Mercury Centrum & České Budějovice & & & \\
\hline
\end{tabular}

Tab. 1: List of shopping centres (ranked according to the date of opening)

Source: Retail Book (2010, 2014); author's survey based on the websites of the particular shopping centres 


\begin{tabular}{|c|c|c|c|c|c|}
\hline \multicolumn{6}{|c|}{ Slovak Republic } \\
\hline No. & Name & City & No. & Name & City \\
\hline 1 & Polus City Center & Bratislava & 26 & Galéria Dunajská Streda & Dunajská Streda \\
\hline 2 & Danubia & Bratislava & 27 & Jasna Shopping City & Liptovský Mikuláš \\
\hline 3 & Aupark & Bratislava & 28 & Zemplín & Michalovce \\
\hline 4 & Cassovia Košice & Košice & 29 & Galéria Nitra & Nitra \\
\hline 5 & Dubeň Žilina & Žilina & 30 & ZOC MAX Prešov & Prešov \\
\hline 6 & Avion Shopping Park & Bratislava & 31 & Apollo Business Center II & Bratislava \\
\hline 7 & Optima Košice & Košice & 32 & Galéria Košice & Košice \\
\hline 8 & Saratov Bratislava & Bratislava & 33 & Galéria Mlyny & Nitra \\
\hline 9 & Shopping Palace Zlaté Piesky & Bratislava & 34 & Madaras & Spišská Nová Ves \\
\hline 10 & ZOC MAX Trnava & Trnava & 35 & Laugaricio Trenčín & Trenčín \\
\hline 11 & Apollo Business Center I & Bratislava & 36 & Galleria Eurovea & Bratislava \\
\hline 12 & OC Mólo & Pezinok & 37 & Galéria Cubicon & Bratislava \\
\hline 13 & ZOC MAX Poprad & Poprad & 38 & Aupark Pieštany & Pieštany \\
\hline 14 & ZOC MAX Trenčín & Trenčín & 39 & OC Korzo Prievidza & Prievidza \\
\hline 15 & Europa Banská Bystrica & Banská Bystrica & 40 & Aupark Žilina & Žilina \\
\hline 16 & Tulip Center & Martin & 41 & Mirage Žilina & Žilina \\
\hline 17 & Centro Nitra & Nitra & 42 & Aupark Košice & Košice \\
\hline 18 & ZOC MAX Nitra & Nitra & 43 & Centrál Bratislava & Bratislava \\
\hline 19 & Galéria Trnava & Trnava & 44 & Trnava Park & Trnava \\
\hline 20 & OC Hron & Bratislava & 45 & Europa Zvolen & Zvolen \\
\hline 21 & ZOC MAX Dunajská Streda & Dunajská Streda & 46 & TMT Trnava & Trnava \\
\hline 22 & Aquario Nové Zámky & Nové Zámky & 47 & Bory Mall & Bratislava \\
\hline 23 & ZOC MAX Skalica & Skalica & & & \\
\hline 24 & ZOC MAX Žilina & Žilina & & & \\
\hline 25 & Galéria Bratislava-Lamač & Bratislava & & & \\
\hline
\end{tabular}

Tab. 1 continued

\begin{tabular}{lll}
\hline A) Exogenous factors & B) Endogenous factors & C) Complex factors \\
\hline A1 Locality/Accessibility & B1 Size of leasable area & C1 Subjective categorization \\
A2 Parking & B2 Number/Structure of businesses & \\
A3 Potential customers & B3 Entertainment and leisure & \\
\hline
\end{tabular}

Tab. 2: Factors determining the attractiveness of shopping centres

Source: authors' design

insufficient. Final limits for the selected shopping centre categories were calculated by means of weighted averages of the proposed limits for the individual categories.

Other attributes of attractiveness, in the context of the size of the city's population, as well as the influence of factors on aggregate attractiveness, were evaluated on the basis of descriptive statistics. The results of these analyses were processed in graphics (CorelDRAW) and cartography (ArcMap) programs.

The data can be divided into four groups. The first group includes data from internal databases of the authors of this article, i.e. continuously collected data related to the retail field development and transformation within the particular country. The second group of data include internal databases of the individual shopping centres, focused on their internal structures and their retailing facilities. The third group includes internal databases of the INCOMA and GfK survey agencies for recent years (2015). The last data group is based on field research. These data form the basis for our empirical approach to resolving these issues.

\section{Results}

The aggregate attractiveness of the shopping centres (AM) was analysed by the combination of the exogenous (A1A3), endogenous (B1-B3) and complex factors (C1). In the following graphs (Fig. 1), indicators for individual Czech and Slovak shopping centres are presented.

Location and accessibility (A1) are the essential exogenous factors determining the attractiveness of a shopping centre. In this article, location is understood within the wider context of shopping centre accessibility, and was quantified from the centre of the city road network to the location of the shopping 
centre, considering that cars are the most frequent means of transportation for shopping. The average accessibility of a shopping centre is 9.4 minutes in the Czech Republic and 6.4 minutes in Slovakia (Tab. 3). The value of the A1 factor exceeds the average (65.1\%) in the Czech Republic for most shopping centres. This factor reaches below-average values for the shopping centres in Slovakia (48.9\%). This selected indicator for shopping centre accessibility obtains higher values in smaller towns than in large cities (Fig. 1), as the centres are more accessible. On the contrary, shopping centres are frequently located at peripheries in more populous cities, resulting in higher travel costs.

The numbers of parking spaces are based on the shopping centre data. The average number of parking spaces per a shopping centre is 1,002 in the Czech Republic and 866 in Slovakia. For this indicator, the attractiveness of shopping centres reaches higher values in more populous cities than in less populous ones with regard to the numbers of potential consumers. It should be noted that shopping centres without available parking spaces were built both in the Czech Republic and in Slovakia (e.g. Galerie Moritz in Olomouc or SC Mirage in Žilina). These shopping centres are located in historical city centres.

A shopping centre's success depends on potential consumers (Huff, 1963), who are influenced by the shopping centre's attractiveness. Potential consumer quantification is based on the catchment area specification (Dennis et al., 2002) within a distance of $30 \mathrm{~km}$ using the Network Analyst tool from the ArcGIS environment. Empirically, we estimate that about $85 \%$ of consumers are included in these zones. The average number of potential consumers (A3) of Czech shopping centres is 720,943 and the difference between the minimum and the maximum is about tenfold. The average Slovak shopping centre has 356,780 potential consumers.

The endogenous factors represent the second group for this evaluation. The 'size of the leasable area' (B1) is one of the basic indicators of shopping centre classification (Lambert, 2006), and also of shopping centre attractiveness (cf. Coleman, 2012). The average Gross Leasable Area (GLA) of a Czech shopping centre $\left(26,799 \mathrm{~m}^{2}\right)$ is almost $5,000 \mathrm{~m}^{2}$ larger than that in Slovakia $\left(21,946 \mathrm{~m}^{2}\right)$. While the smallest centres in both countries are comparable, the difference between the largest shopping centre in the Czech Republic (OC Letňany in Prague, $125,000 \mathrm{~m}^{2}$ ) and the one in Slovakia (Avion Shopping Park in Bratislava, 84,000 $\mathrm{m}^{2}$ ) is over $50,000 \mathrm{~m}^{2}$. The GLA is linked to the number of businesses (stores) and also to the location of significant magnets in the shopping centres. The smaller shopping centres that are characteristic of smaller towns, still significantly lag behind in their aggregate attractiveness.

The structure and the number of businesses (B2) are conditioned by the location of the magnet within the shopping centre. Brown (1993) calls this "magnet" as such stores that initially attract customers (according to Prendergast et al., 1998). The attractiveness of the magnet within a shopping centre draws not only higher consumer attention but also higher retail business concerns. The number of retail facilities indicates that the larger and frequently also more suitable mix of shops determine consumers' decision-making (Wakefield and Baker, 1998). The shopping centres are mutually comparable in the number of retail facilities in both countries. More numerous businesses are characteristic for Slovak shopping centres with GLAs smaller than those in the Czech Republic. Conversely, Czech shopping centres feature smaller numbers of business facilities within larger GLAs.

In the case of the indicator of entertainment and leisure (B3), the authors selected only the existence of a multiplex cinema with more than two theatres and with a common cinema format or IMAX large-scale cinema system with 3 -D technology. Other potential attractors of entertainment and leisure time spending (gaming facilities, fitness centres, bowling, children's areas, climbing walls, etc.) hardly exert such a "mass" attractiveness for the visitors as the multiplex cinemas, not only in the Czech Republic but also in Slovakia (Ooi and Sim, 2007).

The complex factor (C1) was the last evaluated factor, based on a subjective categorization, representing the empirical approach of specialists from the fields of geography and economics. They established the subjective measure of

\begin{tabular}{|c|c|c|c|c|c|c|c|}
\hline & & $\mathbf{N}$ & Minimum & Maximum & Mean & Std. Deviation & $\begin{array}{l}\text { t-values; } d f=128 \\
\text { probability levels }\end{array}$ \\
\hline \multirow[t]{2}{*}{$\mathrm{A} 1$} & $\mathrm{SC}$ in $\mathrm{CR}$ & 83 & 2 & 27 & 9.40 & 6.57 & \\
\hline & $\mathrm{SC}$ in $\mathrm{SR}$ & 47 & 1 & 16 & 6.40 & 3.65 & $\mathrm{t}=2.89 ; \mathrm{p}<0.005$ \\
\hline \multirow[t]{2}{*}{ A2 } & $\mathrm{SC}$ in $\mathrm{CR}$ & 83 & 0 & 4,027 & 1,002 & 814.22 & $\mathrm{t}=0.98 ; \mathrm{ns}$ \\
\hline & $\mathrm{SC}$ in SR & 47 & 0 & 3,200 & 866 & 649.03 & \\
\hline \multirow[t]{2}{*}{ A3 } & $\mathrm{SC}$ in $\mathrm{CR}$ & 83 & 115,542 & $1,575,650$ & 720,943 & $545,402.85$ & $\mathrm{t}=4.46 ; \mathrm{p}<0.0001$ \\
\hline & $\mathrm{SC}$ in $\mathrm{SR}$ & 47 & 89,373 & 686,451 & 356,780 & $161,395.09$ & \\
\hline \multirow[t]{2}{*}{ B1 } & $\mathrm{SC}$ in $\mathrm{CR}$ & 83 & 5,700 & 125,000 & 26,799 & $22,635.82$ & $\mathrm{t}=1.42 ; \mathrm{ns}$ \\
\hline & $\mathrm{SC}$ in $\mathrm{SR}$ & 47 & 5,200 & 84,000 & 21,489 & $16,184.51$ & \\
\hline \multirow[t]{2}{*}{ B2 } & $\mathrm{SC}$ in $\mathrm{CR}$ & 83 & 15 & 250 & 81 & 50.48 & $\mathrm{t}=0.86 ; \mathrm{ns}$ \\
\hline & $\mathrm{SC}$ in SR & 47 & 24 & 268 & 89 & 50.61 & \\
\hline \multirow[t]{2}{*}{ B3 } & $\mathrm{SC}$ in $\mathrm{CR}$ & 83 & 0 & 42 & 4.30 & 7.42 & $\mathrm{t}=0.24 ; \mathrm{ns}$ \\
\hline & $\mathrm{SC}$ in $\mathrm{SR}$ & 47 & 0 & 21 & 4.00 & 5.68 & \\
\hline \multirow[t]{2}{*}{$\mathrm{C} 1$} & $\mathrm{SC}$ in $\mathrm{CR}$ & 83 & 1.0 & 5.0 & 3.27 & 1.03 & $\mathrm{t}=2.16 ; \mathrm{p}=0.033$ \\
\hline & $\mathrm{SC}$ in SR & 47 & 1.8 & 5.0 & 3.65 & 0.83 & \\
\hline
\end{tabular}

Tab. 3: Descriptive statistics of attractiveness factors of shopping centres in the Czech and Slovak Republics Legend: SC-shopping centre. Probability levels ( $n$ s = non-significant). Source: authors' survey 

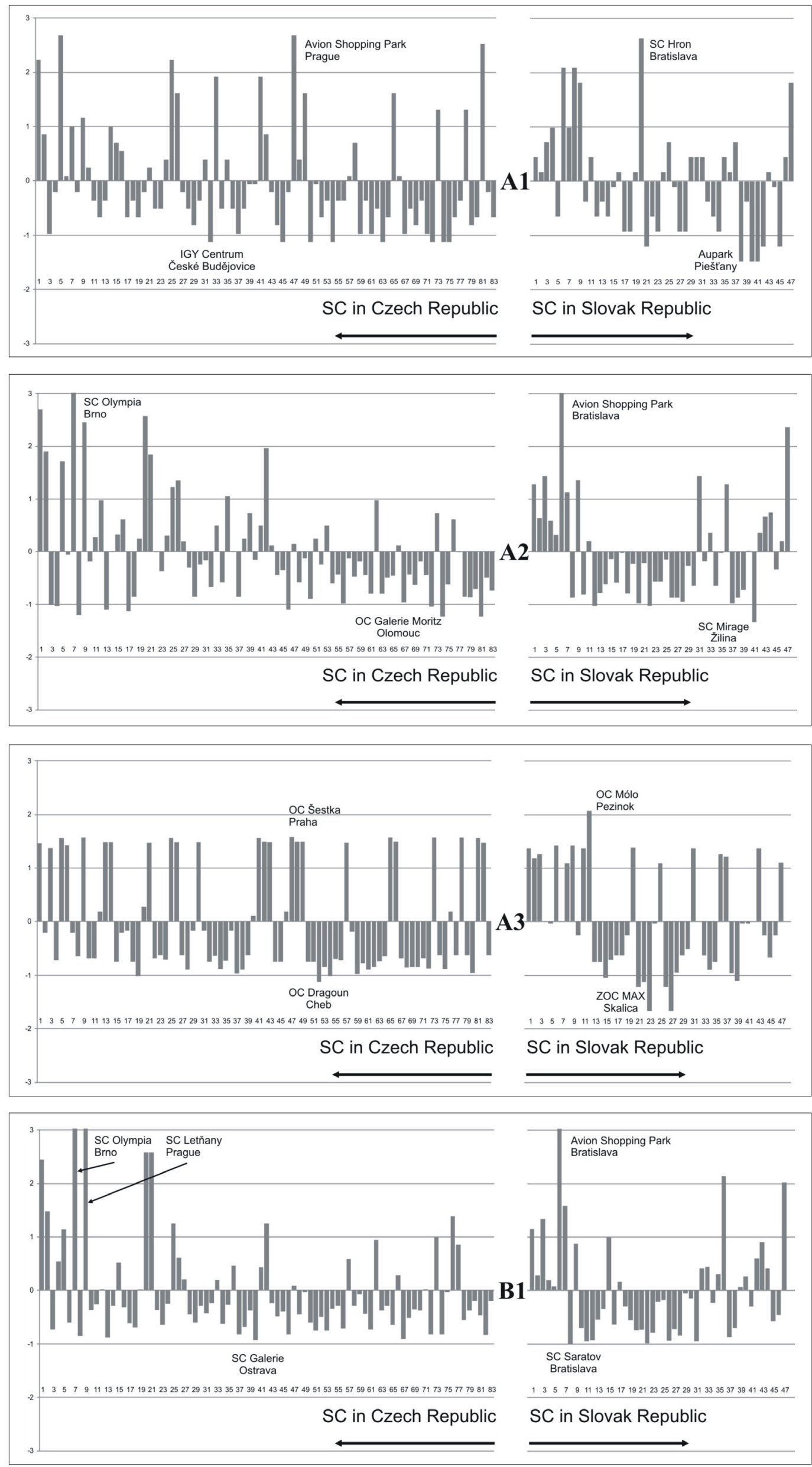

Fig. 1: The attractiveness indicators expressed by endogenous, exogenous and subjective factors (standardised values) 

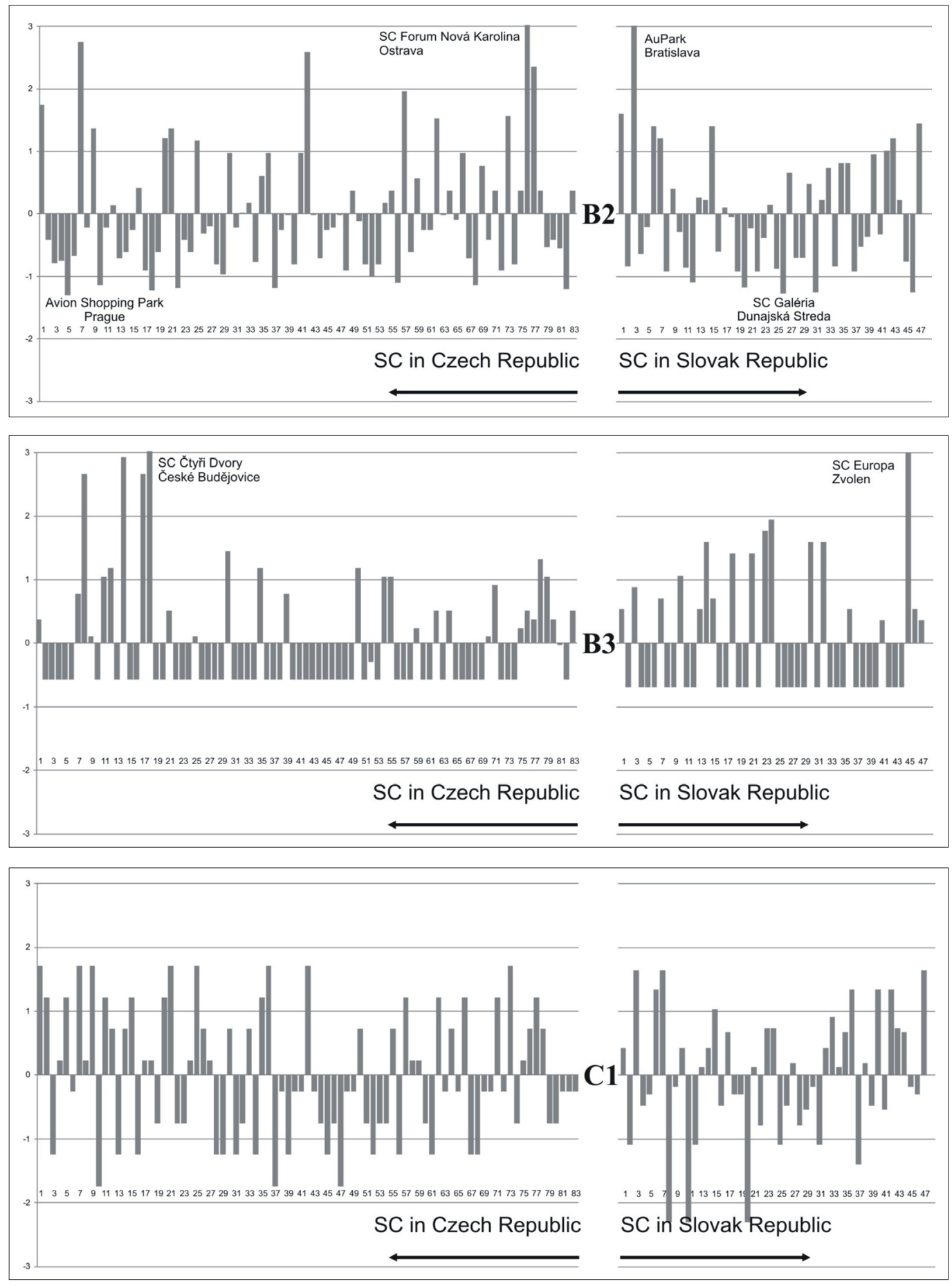

Fig. 1 continued

attractiveness (on a scale from 1 to 5 , where $1=$ the most attractive and $5=$ the least attractive) for all of the assessed shopping centres. The Slovak shopping centres are considered less attractive due to a lower average attractiveness level (3.1 from the 5-degree scale). The specialists from the Czech Republic assessed the average level of shopping centre attractiveness at 2.7. The different values could be influenced by the different numbers of the evaluated shopping centres and by their distribution in space, and by different concentrations in the capital cities of both countries.

The aggregate attractiveness (AM) is based on data from all the assessed factors (A1, A2, A3, B1, B2, B3 and C1) as judged by specialists, who determined five intervals for the individual categories of shopping centre attractiveness (Fig. 2).
From these data, we determined five categories of shopping centres according to their attractiveness (Tab. 4). The shopping centres with limited attractiveness are the most numerous group and they represent approximately one-third of all shopping centres in the Czech Republic. A higher number of this category's centres are located in the north-west of the country (Fig. 3). This could be due to their concentration in a strongly urbanised, but structurally (industrially) affected territory with high unemployment rates and lower purchasing power of the local population, resulting in fewer shopping trips and a lower attractiveness of the shopping centres. The category ranked second in the Czech Republic includes shopping centres with very high attractiveness levels. These are mostly shopping centres 


\begin{tabular}{cccccccc}
\hline & & N & I. category & II. category & III. category & IV. category & V. category \\
\hline \multirow{2}{*}{$\mathrm{AM}$} & $\mathrm{SC}$ in $\mathrm{CR}$ & 83 & 26.5 & 13.3 & 20.5 & 33.7 & 6.0 \\
& $\mathrm{SC}$ in SR & 47 & 17.0 & 14.9 & 36.2 & 21.3 & 10.6 \\
\hline
\end{tabular}

Tab. 4: Categories of shopping centres in the Czech Republic (CR) and the Slovak Republic (SR) (Share of shopping centres in \%). Source: authors' surveys

Legend: $I$. = very high attractiveness; II. = moderately highattractiveness; III. = average attractiveness; IV. = limited attractiveness; $V .=$ insufficient attractiveness

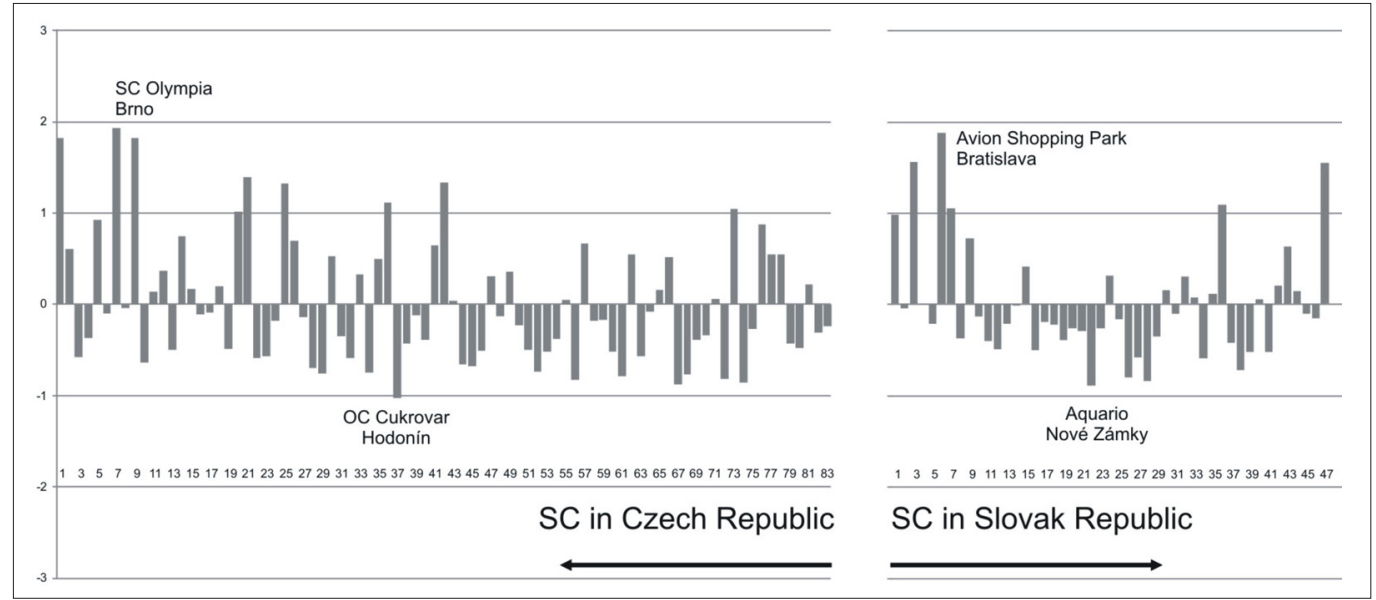

Fig. 2: Aggregate attractiveness (standardised values)

Source: authors' surveys

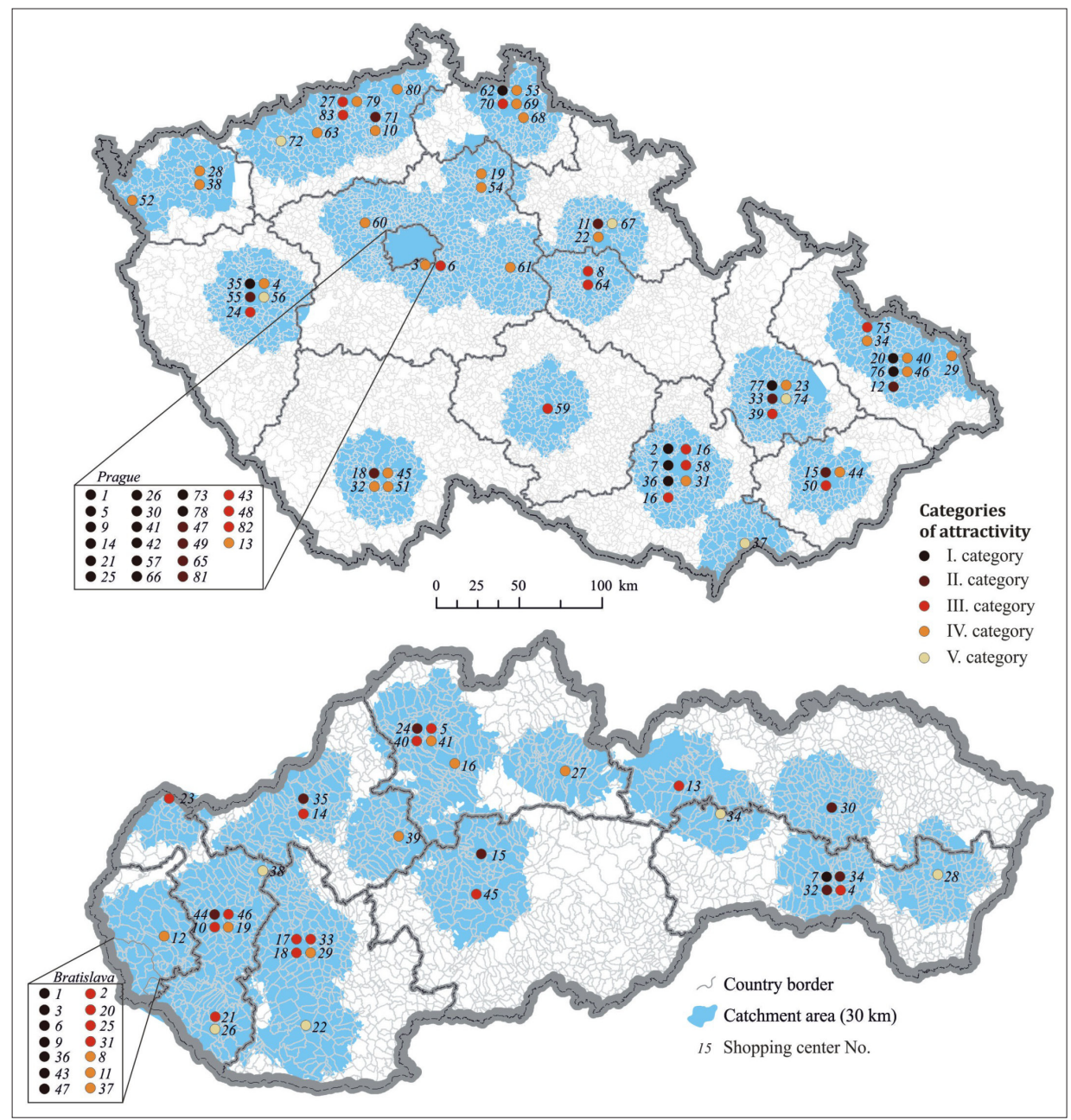

Fig. 3: Classification of shopping centres according to their attractiveness in the Czech and Slovak Republics Source: authors' surveys 
located in the capitals. For example, over one-half of all shopping centres in Prague fall into this category. Onefifth of Czech shopping centres are centres with average attractiveness and they exhibit a relatively uniform distribution in space. The smallest number of shopping centres was included in the group designated (according to the factors analysed) as insufficient-attractiveness centres. These are either shopping centres located in towns with small numbers of inhabitants (former district towns, such as Hodonín, Chomutov and others), or shopping centres complementing retail facilities in towns with multiple shopping centres (such as the regional towns of Olomouc and Plzeň).

The shopping centres with 'average attractiveness' comprise the most numerous group in the Slovak Republic (36.2\%). These shopping centres are located in both large and smaller towns (by population). It is possibly related to the structure of the regional population distribution and regional economic development within the context of regional disparities in Slovakia. Over one-fifth of all shopping centres in the country are shopping centres with limited attractiveness, located mainly in western and northern Slovakia - areas with lower purchasing power of the local populations, daily trips to more populous towns and shopping there, over-the-border shopping and the general economic situation. In comparison, very high attractiveness is typical only for the Slovak metropolises, Bratislava and Košice (Fig. 3)
To analyse the aggregate attractiveness of the shopping centres, we evaluated its association with the size of the city's population $^{2}$ (Fig. 4). On the one hand, it is possible to observe the concentration of the most attractive shopping centres in the most populous cities. Conversely, the least attractive centres are typical for the less densely populated cities in the Czech and Slovak Republics as well. It may also be noted that in populous cities, there are also less attractive shopping centres.

For illustration, we consider only the two largest cities, which are natural development poles and economic drivers of the Czech Republic (the capital city of Prague and Brno) and Slovakia (the capital Bratislava and Kosice). The shopping centres with less extent of attractiveness can be divided into three groups (Tab. 5). In the first case, one registers the shopping centres which are located mainly in the peripheral parts of cities, mostly built on greenfields and difficult to access by public transport. The second type represents centres that are part of different multifunctional spaces, especially in combination with residential and administrative functions, with modern and luxurious office space with shared entrance areas and a distant and unapproachable effect on the number of potential customers, weakening "more massive" interest in this type of centre. A third type of shopping centre is the one with specialised shops and selected brands targetted to a specific clientele, which includes not only more expensive brands of fashion, footwear and fashion accessories, but also gastronomic facilities,

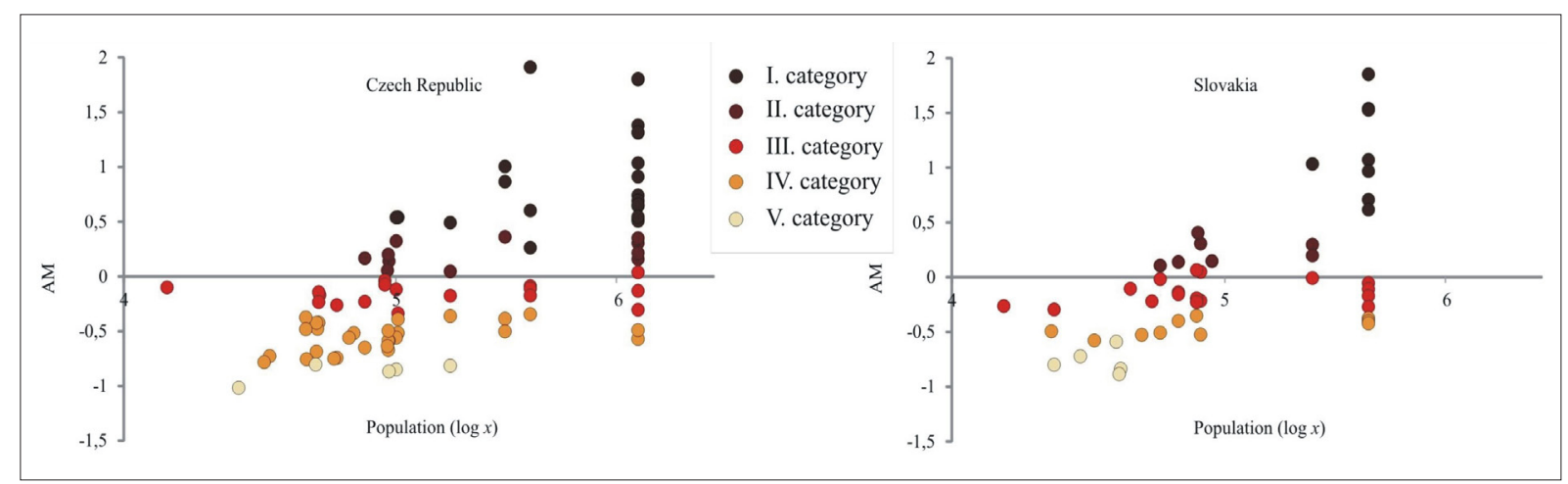

Fig. 4: Dependence of attractiveness of shopping centres on the population size of cities Source: authors' surveys

\begin{tabular}{|c|c|}
\hline Czech Republic & Slovakia \\
\hline \multicolumn{2}{|l|}{ I. Type: Peripheral localization } \\
\hline Spectrum Průhonice Prague (3) & Saratov Bratislava (8) \\
\hline SC Královo Pole Brno (31) & Cassovia Košice (4) \\
\hline \multicolumn{2}{|l|}{ II. Type: Multifunctional centre } \\
\hline \multicolumn{2}{|l|}{ Florentinum Prague (82) } \\
\hline Campus Square Brno (58) & Apollo Business Center Bratislava $(11,31)$ \\
\hline \multicolumn{2}{|l|}{ III. Type: Specific clientele } \\
\hline Florentinum Prague (82) & Cubicon Bratislava (37) \\
\hline
\end{tabular}

Tab. 5: Typology of shopping centres with lower attractiveness in the Czech and Slovak Republics (Note: Numbers correspond with the list of shopping centres in Figure 1)

Source: authors' surveys

\footnotetext{
2 The outlet centres located in rural municipalities, are certain exceptions. One example of such an outlet centre is in Voderady near the town of Trnava in Slovakia (Civáň et al., 2014)
} 
services and facilities for entertainment and leisure. These centres are generally not attractive enough for the lower and middle classes, influencing attendance the most.

Aggregate attractiveness (AM) is affected by the analysed factors in different ways (Fig. 5). In general, the most significant positive correlation with aggregate attractiveness was estimated for the indicators $\mathrm{B} 1$ and $\mathrm{B} 2$, and it is a strong correlation in both countries. The significant impact of the size of leasable area (tenant mix) on the attractiveness is confirmed by several studies (Teller, 2008). Second, positive correlations were also observed for the number of parking places (cf. Reutterer and Teller, 2008). Average correlations are typical for the factors A1, A3 and C1. The accessibility of the shopping centres, with respect to the number of potential consumers does not play an important role in our study. On the other hand, it is important to note that the subjective factors also significantly influence the results of the analysis. The multiplex cinemas, as the main representative of additional services (B3) of Czech and Slovak shopping centres, have only weak, but positive impacts on the aggregate attractiveness. One reason for this could be the fact that $3 / 5$ of all shopping centres are missing these facilities in both countries.

\section{Conclusions}

Although many studies have focused on the topic of shopping centres in Czech and Slovak geography (e.g. Civán et al., 2014; Fertal'ová, 2005, 2006; Klapka et al., 2013; Križan et al., 2014; Kunc et al., 2011, 2012b , 2013; Maryáš et al., 2014; Mitríková, 2008; Trembošová, 2009, 2012; Spilková, 2003, 2010, 2012a, 2012b; Spilková, Hochel', 2009; Szczyrba, 2004,2005), an empirical study of the attractiveness of shopping centres has not been conducted in the Czech or Slovak research literature. We conclude that the evaluation of the attractiveness of the shopping centres, as a dynamic element of Central and Eastern European countries, is quite complex and to some extent a subjective task. In this paper, we referred to earlier published scientific studies measuring the attractiveness of the retail environment (especially shopping centres): for example, using agglomeration attributes (Teller, Elms, 2010); the catchment area (Dolega et al., 2016); central place theory and the retail hierarchy (Dennis et al., 2002b); or, directly according to respondents' consumer preferences (Dennis et al., 1999). Furthermore, we also took into account some of the specific conditions of the Czech-Slovak retail environment and the post-1989 market in the CEE countries. We also used an evaluation of the attractiveness of the shopping centres by a group of experts. The aggregate attractiveness is a combination of objective and subjective factors.

The results of the study answer the research questions. The shopping centres can be generally considered as more attractive in the Czech Republic (Q1). More than onequarter of the shopping centres can be specified with a high level of attractiveness in the Czech Republic, although this proportion is less than one-fifth in Slovakia. The economic situation and the spatial distribution of the shopping centres play a significant role in both countries. The average leasable area is more than $5,000 \mathrm{~m}^{2}$ greater than the Slovak case for shopping centres in the Czech Republic (Kunc et al., 2013). On the other hand, tenant mix is diversified on average in the case of shopping centres in Slovakia. Even though tenant mix is considered the most important factor of attractiveness (Teller, 2008), it was not primarily expressed in aggregate attractiveness.

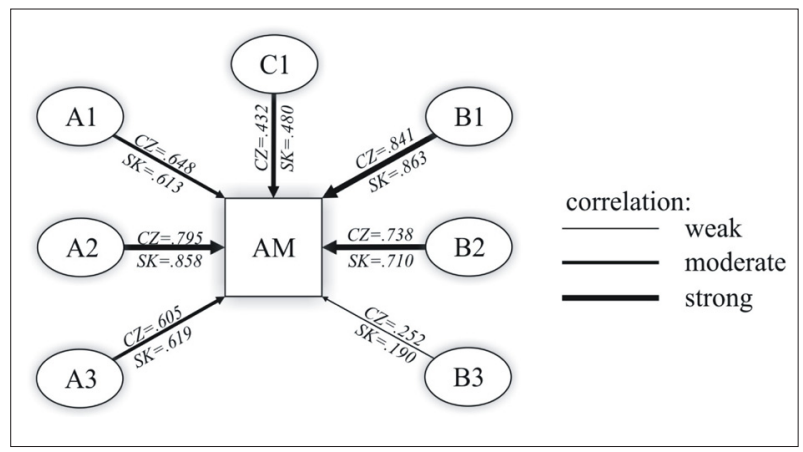

Fig. 5: Correlations of analysed factors and aggregate attractiveness $(C Z=$ Czech Republic, $S K=$ Slovakia $)$ Source: authors' surveys

In general, the attractiveness of shopping centres in more populous cities is higher than the attractiveness in cities with smaller population (Q2). The attractiveness of shopping centres reached the highest values in the capitals of both countries. On the contrary, the attractiveness of the less populous towns (less than 50,000 inhabitants) does not reach values higher than the average (III. category). On the other hand, attractiveness was measured at the national level. Local attractiveness, measured by consumer preferences, can achieved and often with different values. Generally, less attractive shopping centres can be divided into three groups based on their location, the (administrative/residential) functions and the targetting of specific clientele.

Aggregate attractiveness is influenced by various factors in different ways (Q3). The analysis of the attractiveness of shopping centres in the Czech Republic and Slovakia confirmed the importance of selected endogenous factors. The most important of these include "GLA" and "tenant mix". On the other hand, exogenous factors such as "parking" and the factor of "accessibility" play important roles. The endogenous factor B3, which represents attractiveness in the context additional services (multiplex cinema), obtained the lowest level of correlation. It turned out that this factor had the lowest impact on the attractiveness of the shopping centres in both countries. Following the selected methodological approach, 'subjective categorization of the shopping centres' has no significant impact on the results of the analysis. It should be noted, however, that we found positive correlations between the assessed factors and aggregate attractiveness in all bivariate associations.

The results of the present comparative study can be generalized to the Central European level. The empirical results can be compared within any standard market environment in the world. Among the generalized implications of the research questions, it is possible to assert the following:

- the theoretical and methodological approach to measure the attractiveness of shopping centres is supported by a number of similar studies from other foreign countries;

- the variables used (factors determining attractiveness) are typical for most shopping centres in the world and they cannot be ignored in similar analyses;

- the theoretical assumptions of the significance of the tenant mix has been empirically supported, i.e. tenant mix is a decisive endogenous factor in the attractiveness of shopping centres. This finding brings additional insights for the practice of marketing planning; and 
- the empirical evidence from both countries, as examples of post-socialist countries largely affected by the transformation of the retail environment and by the dynamic development of the construction of shopping centres, is directly applicable to the practice of marketing, in terms of the optimal arrangement of retail space and financial returns.

The authors of this paper are also aware of the limiting factors of this study, which can be characterized in three ways. The first can be matched with the notions of Dolega et al. (2016, p. 81) "It should be highlighted that although such indicators might influence our choice of a shopping destination, it may not be feasible to measure them on a systematic basis across a national extent". The transboundary impacts were not taken into account in our analysis. Cross-border shopping and visits to the shopping centres across borders is relatively common in the Shengen space. This phenomenon is also characteristic for the Czech Republic and Slovakia (cf. Civáň and Krogman, 2013; Dołzbłasz, 2015). A second aspect is based on the method of enumeration of aggregate attractiveness. This is a sample of respondents, experts from various disciplines, who subjectively evaluated the attractiveness of shopping centres. Consumers' opinions could be quite different. The third limiting factor is based on different perspectives to measure attractiveness, as any single measure of attractiveness is far from comprehensive (Timmermans, 1996). The results of this sub-analysis indicate that the aggregate attractiveness is as defined by the authors. On the other hand, it is possible to encounter various 'sub'-dimension of attractiveness. For example, the Tellerr and Reutterer (2008) analysis is based on three dimensions (overall attractiveness, situational attractiveness and sustainable attractiveness). This aspect of the work represents a possible direction for future research. Also, measuring the attractiveness of one town with the "in vivo" approach is a topic for future studies in post-socialist countries.

\section{Acknowledgements}

This contribution was supported by the VEGA project "Specifics of time-space human behaviour under the impact of socio-economic changes" (No. 1/0082/15); by the VEGA project "Social, economic and environmental determinants of regional development and transformation: a regional geographic approach" (No. 1/0540/16; and by an internal grant "Shopping centres and shopping habits of teenagers: Brno case study" of the Faculty of Economics and Administration, Masaryk University (MUNI/A/0943/2015).

\section{References:}

ABRATT, R, FOURIE, J. L., PITT, L.F. (1985): Tenant mix: the key to a successful shopping centre. Quarterly Review of Marketing, 15: 19-27.

ALZUBAIDI, H., VIGNALI, C., DAVIES, B. J., SCHMIDT, R. A. (1997): Town centre versus out-of-town shopping: a consumer perspective. International Journal of Retail and Distribution Management, 25(2): 78-89.

ARENTZE, T. A., TIMMERMANS, H. J. P. (2001): Deriving performance indicators from models of multipurpose shopping behavior. Journal of Retailing and Consumer Services, 8(6): 325-334.

AWANG, Z., AMINUDIN, N., HASHIM, N. N., MUSTAPHA, N.A. (2013): Shopping mall attractiveness: Factors affecting consumer decision towards visitation. Hospitality and Tourism: Synergizing Creativity and Innovation in Research, 147.

BEAN, J. C., NOON, C. E., RYAN, S. M., SALTON, G. J (1988): Selecting tenants in a shopping mall. Interfaces, 18(2): 1-9.

BROWN, S. (1993): Micro-scale retail location: Cinderella or ugly sister? International Journal of Retail \& Distribution Management, 21(7): 10-19.

BURNS, D. J., WARREN, H. B. (1995): Need for uniqueness: shopping mall preference and choice activity. International Journal of Retail and Distribution Management, 23(12): 4-12.

CIVÁŇ, M., KROGMANN, A. (2013): Nákupný turizmus medzi Slovenskom a Rakúskom, Geografické informácie, 16(1): 42-50.

CIVÁŇ, M., SVORAD, A., KROGMAN, A. (2014): Outlet centre as a potential development impulse: a case study of the municipality of Voderady. In: Polak, O. et al. [ed.]. Conference: $21^{\text {st }}$ International Ph.D. Students Conference (pp. 340-344). Location: Mendel Univ, Brno (Fac Agron).

COLEMAN, P. (2012): Shopping Environments. London, Routledge.

COOPER, D. (2007): Being in Public: The Threat and Promise of Stranger Contact. Law \& Social Inquiry, 32(1): 203-232.

CRAWFORD, M. (1992): The World in a Shopping Mall. In: M. Sorkin (ed.), Variations on a theme park. The new American city and the end of public space (pp. 3-30). New York, Hill and Wang.

CUSHMAN \& WAKEFIELD (2011): European Shopping Centre Development Report September 2011. In: Cushman \& Wakefield: Knowledge Center [online]. Available at: <http://www.cushwake.be/cwglobal/jsp/kcReportDetail. jsp?Country $=$ EMEA\&Language $=$ EN\&catId $=700003 \& p I d=c 37800004 p>$

DĘBEK, M. (2015): What Drives Shopping Mall Attractiveness? Polish Journal of Applied Psychology, 13(1): 67-118.

DENNIS, C., MARSLAND, D., COCKETT, T. (1999): Why do people shop where they do? Recent Advances in Retailing and Services Science. Proceedings of the $6^{\text {th }}$ International Conference. The European Institute of Retailing and Services Studies. Eindhoven: The Netherlands.

DENNIS, C., MARSLAND, D., COCKETT, T. (2002b): Central place practice: shopping centre attractiveness measures, hinterland boundaries and UK retail hierarchy. Journal of Retailing and Consumer Services, 9: 185-199.

DENNIS, C., MURPHY, J., MARSLAND, D., COCKETT, T., PATEL, T. (2002a): Measuring image: shopping centre case studies. The International Review of Retail, Distribution and Consumer Research, 12(4): 355-373.

DOLEGA, L., PAVLIS, M., SINGLETON, A. (2016): Estimating attractiveness, hierarchy and catchment area extents for a national set of retail centre agglomerations. Journal of Retailing and Consumer Services, 28: 78-90.

DOŁZBŁASZ, S. (2015): Symmetry or asymmetry? Crossborder openness of service providers in Polish-Czech and Polish-German border towns. Moravian Geographical Reports, 23(1): 2-12. 
DONOVAN, R. J., ROSSITER, J. R. (1982): Store atmosphere: an environmental psychology approach. Journal of retailing, 58(1): 34-57.

FERTALOVÁ, J. (2005): Some methodological issues in classification of retail stores (with examples from European countires). Folia geographica, 8, 13-19.

FERTALOVÁ, J. (2006): Evaluation of attendance in selected hypermarkets and shopping stores in the towns of Prešov and Košice. Acta Universitatis Palackianae Olomucensis Facultas Rerum Naturalium, Geographica, 39(1): 19-29.

FINN, A., LOUVIČRE, J. J. (1996): Shopping center image, consideration, and choice: anchor store contribution. Journal of business research, 35(3): 241-251.

GARG, A. K., STEYN, S. (2014): The Ideal Tenant Mix and Shopping Centre Size for the Proposed Thatchfield Convenience Centre. International Journal of Business and Management, 10(1): 243-257.

GHOSH, A. (1986): The value of a mall and other insights from a revised central place model. Journal of retailing, 62(1): 79-97.

GIDDENS, A. (2002): Runway World. How Globalization is Reshaping Our Lives. London, Profile Books.

GOLLEDGE， R. G. J., STIMSON， R. J. (1997): Spatial Behavior: A Geographic Perspective. New York, Guilford Press.

GROSMANOVÁ, M., KITA, P., ŽAMBOCHOVÁ, M. (2015): Segmentation of Consumers in the Context of their Space Behaviour: Case Study of Bratislava. Prague Economic Papers, 24(5): 1-15.

GUY, C. M. (1998): Controlling new retail spaces: The impress of planning policies in Western Europe. Urban Studies, 35(5-6): 953-979.

HUFF, D. L. (1963): A probabilistic analysis of shopping center trade areas. Land economics, 39(1): 81-90.

IBRAHIM, M., MCGOLDRICK, P. (2003): Shopping choices with public transport options: an agenda for the 21st century. Ashgate, Hampshire UK.

ICSC RESEARCH (2005): Towards a Pan-European Shopping Centre Standard-A Framework for International Comparison. New York, International Council of Shopping Centers.

INCOMA \& GFK (2015): Shopping monitor 2015 [online]. Available at: <http://incoma.cz/wp-content/uploads/2014/05/ Incoma-Shopping-Monitor-2015-obsah.pdf>

JACKSON, V., STOEL, L., BRANTLEY, A. (2011): Mall Attributes and Shopping Value: Differences by Gender and Generation Cohort. Journal of Retailing and Consumer Services, 18(1): 1-9.

KITA, P., GROSMANOVÁ, M. (2014): Reflection of Bratislava Retail Network in Selected Aspects of Consumer Behaviour. Verslas: teorija ir praktika, 15(3): 279-284.

KLAPKA, P., ERLEBACH, M., KRÁL, O., LEHNERT, M., MIČKA, T. (2013): The footfall of shopping centres in Olomouc (Czech Republic): an application of the gravity model. Moravian Geographical Reports, 21(3): 12-26.

KRIŽAN, F. (2009). Globalizácia maloobchodu: definícia základných procesov a ich analýza v slovenskej geografii maloobchodu. Geografický časopis, 61(1): 49-68.
KRIŽAN, F., BILKOVÁ, K., KITA, P. (2014): Urban retail market in Bratislava (Slovakia): Consumers perception and classification of shopping centres. Management \& Marketing, 9(4): 483-500.

KUNC, J., FRANTÁL, B., SZCZYRBA, Z., TONEV, P., TOUŠEK, V. (2011): Shopping centres and shopping behaviour: selected relations and socio-geographical implications (The Vaňkovka Gallery Brno, Czech Republic example). Acta Universitatis Palackianae Olomucensis Facultas Rerum Naturalium-Geographica, 42(1): $5-17$.

KUNC, J., FRANTÁL, B., TONEV, P., SZCZYRBA, Z. (2012a): Spatial Patterns of Daily and Non-daily Commuting for Retail Shopping: Case of the Brno City, Czech Republic. Moravian Geographical Reports, 20(4): 39-54.

KUNC, J., TONEV, P., SZCZYRBA, Z., FRANTÁL, B. (2012b): Shopping centres and selected aspects of shopping behaviour (Brno, the Czech Republic). Geographia Technica, 7(2): 39-51.

KUNC, J., TONEV, P., SZCZYRBA, Z., GREPLOVÁ, Z. (2012c): Perspektivy nákupních center v České republice $\mathrm{s}$ důrazem na lokalizaci v urbánním prostředí: př́klad města Brna. Urbanismus a územní rozvoj, XV(2): 14-20.

KUNC, J., MARYÁŠ, J., TONEV, P., FRANTÁL, B., SIWEK, T., HALÁS, M., KLAPKA, P., SZCZYRBA, Z., ZUSKÁČOVÁ, V. (2013): Časoprostorové modely nákupního chování české populace. Brno, Masarykova univerzita.

LAMBERT, J. (2006): One Step Closer to a Pan-European Shopping Center Standard. Illustrating the New Framework With Examples. Features, Research Review, 13(2): $35-40$.

LEVY, M., WEITZ, B.A. (2006): Retailing management. Boston: McGraw-Hill.

LUSCH, R. F., SERPKENCI， R. R. (1990): Personal differences, job tension, job outcomes, and store performance: A study of retail store managers. The Journal of Marketing, 54(1): 85-101.

MARJANEN, H. (1995): Longitudinal study on consumer spatial shopping behavior with special reference to out-oftown shopping experiences from Turku, Finland. Journal of Retailing and Consumer Services, 2(3): 163-174.

MARYÁŠ, J., KUNC, J., TONEV, P., SZCZYRBA, Z. (2014): Shopping and Services Related Travel in the Hinterland of Brno: Changes from the Socialist Period to the Present. Moravian Geographical Reports, 22(3): 18-28.

MCGOLDRICK, P. J., THOMPSON, M. G. (1992): The role of image in the attraction of the out-of-town centre. International Review of Retail, Distribution and Consumer Research, 2(1): 81-98.

MEIJA, L. C., EPPLI, M. J. (1999): The effect of merchandise space allocation on retail sales in enclosed shopping centre. Journal of Shopping Centre Research, 6: 23-40.

MICU, C. B. (2013): The concept of shopping centre attractiveness-literature review. Marketing From Information to Decision, 6: 145-157.

MINGARDO, G., Van MEERKERK, J. (2012): Is parking supply related to turnover of shopping areas? The case of the Netherlands. Journal of Retailing and Consumer Services, 19(2): 195-201. 
MITRÍKOVÁ, J. (2008): Geografické aspekty transformácie maloobchodu a nákupného správania sa na Slovensku (prípadové štúdie z miest Prešov a Košice). Prešov: Prešovská univerzita $\mathrm{v}$ Prešove.

NEVIN, J. R., HOUSTON, M. J. (1980): Image as a component of attraction to intraurban shopping areas. Journal of Retailing, 56(1): 77-93.

OOI, J. T. L., SIM, L. L. (2007): The magnetism of suburban shopping centers: Do size and Cineplex matter? Journal of Property Investment and Finance, 25(2): 111-135.

OPPEWAL, H., ALEXANDER, A., SULLIVAN, P. (2006): Consumer perceptions of corporate social responsibility in town shopping centres and their influence on shopping evaluations. Journal of retailing and Consumer services, 13(4): 261-274.

PLĂIAŞ, I., ABRUDAN, I. N. (2013): Use of Tenant Mix Strategies to Attract Shopping Centers' Customers. Evidence from Romania. Marketing From Information to Decision, 6: 23-35.

POSPĚCH, P. (2010): Význam a normalita ve veřejném prostoru a v nákupním centru. In Vacková, B., Ferenčuhová, S., Galčanová, L. [eds.]: Československé město včera a dnes: Každodennost - reprezentace - výzkum. Červený Kostelec, Brno: Pavel Mervart, Masarykova univerzita: 113-136.

POTTER, R. B. (1979): Perception of Urban Retailing Facilities: An Analysis of Consumer Information Fields. Geografiska Annaler, Series B, Human Geography, 61(1): 19-27.

PRENDERGAST, G., MARR, N., JARRAT, B. (1998): Retailers' views of shopping centres: a comparison of tenants and non-tenants. International Journal of Retail \& Distribution Management, 26(4): 162-171.

REILLY, W. J. (1931): The Law of Retail Gravitation, New York.

RETAIL BOOK (2010, 2014) [online]. Available from: < http://centers.viphosting.eu/rb2010/>; < http://centers. viphosting.eu/rb2014/>

RUSHTON, G. (1969): Analysis of Behavior by Revealed Space Preference. Annals of Association of American Geogpraphers, 59(2): 391-400.

SIT, J., MERRILEES, B., BIRCH, D. (2003): Entertainmentseeking shopping centre patrons: the missing segments. International Journal of Retail and Distribution Management, 31(2): 80-94.

SPILKOVÁ, J. (2003): Nový fenomén: nákupní centrum a utváření nákupního chování spotřebitelů v transformačním období. Geografie, 108(4): 277-288.

SPILKOVÁ, J. (2010): Retail Development and Impact Assessment in Czech Republic: Which Tools to Use? European Planning Studies, 18(9): 1469-1484.

SPILKOVÁ, J. (2012a): Geografie maloobchodu a spotřeby. Praha, Karolinum.

SPILKOVÁ, J. (2012b): The Birth of the Czech Mall Enthusiast: The Transition of Shopping Habbits from Utilitarian to Leisure Shopping. Geografie, 117(1): 21-32.

SPILKOVÁ, J., HOCHEL', M. (2009): Toward the Economy of Pedestrian Movement in Czech and Slovak Shopping Malls. Environment and Behavior, 41(3): 443-455.
SZCZYRBA, Z. (2004): Globalized retail structures in the city of Olomouc (selected issues of branch, regional and social organization). Acta Universitatis Palackianae Olomucensis Facultas Rerum Naturalium, Geographica, 38: 85-91.

SZCZYRBA, Z. (2005): Maloobchod v ČR po roce 1989 vývoj a trendy se zaměřením na geografickou organizaci. Olomouc, Univerzita Palackého.

TELLER, C. (2008): Shopping streets versus shopping mallsdeterminants of agglomeration format attractiveness from the consumers' point of view. The International Review of Retail, Distribution and Consumer Research, 18(4): 381-403.

TELLER, C., REUTTERER, T. (2008): The evolving concept of retail attractiveness: what makes retail agglomerations attractive when customers shop at them? Journal of Retailing and Consumer Services, 15(3): 127-143.

TELLER, C., ALEXANDER, A. (2014): Store managers-the seismographs in shopping centres. European Journal of Marketing, 48(11/12): 2127-2152.

TELLER, C., ALEXANDER, A., FLOH, A. (2016): The impact of competition and cooperation on the performance of a retail agglomeration and it stores. Industrial Marketing Management, 52: 6-17.

TELLER, C., ELMS, J. (2010): Managing the attractiveness of evolved and created retail agglomerations formats. Marketing Intelligence \& Planning, 28(1): 25-45.

TELLER, C., ELMS, J. R. (2012): Urban place marketing and retail agglomeration customers. Journal of Marketing Management, 28(5-6): 546-567.

TELLER, C., ELMS, J. R., THOMSON, J.A., PADDISON, A. R. (2010): Place marketing and urban retail agglomerations: An examination of shoppers' place attractiveness perceptions. Place Branding and Public Diplomacy, 6(2): 124-133.

TELLER, C., REUTTERER, T. (2008): The evolving concept of retail attractiveness: what makes retail agglomerations attractive when customers shop at them? Journal of Retailing and Consumer Services, 15(3): 127-143.

TELLER, C., SCHNEDLITZ, P. (2012): Drivers of agglomeration effects in retailing: The shopping mall tenant's perspective. Journal of Marketing Management, 28(9-10): 1043-1061.

TIMMERMANS, H. J. P. (1996): A stated choice model of sequential mode and destination choice behaviour for shopping trips. Environment and Planning A, 28(1): 173-184.

TIMOTHY, D. J. (2005): Shopping Tourism, Retailing, and Leisure. New York, Channel View Publications.

TREMBOŠOVÁ, M. (2009): Nitra - mesto obchodných centier. Geografické štúdie, 13(1): 69-79.

TREMBOŠOVÁ, M. (2012): Geografické aspekty maloobchodnej siete mesta Nitra. Nitra: UKF.

TURLEY, L. W., MILLIMAN, R. E. (2000): Atmospheric effects on shopping behavior: a review of the experimental evidence. Journal of Business Research, 49(2): 193-211.

VAN DER WAERDEN, P., BORGERS, A., TIMMERMANS, H. (1998): The impact of the parking situation in shopping centres on store choice behaviour. GeoJournal, 45(4): 309-315. 
VAN LEEUWEN, E. S., RIETVELD, P. (2011): Spatial Consumer Behaviour in Small and Medium-sized Towns. Regional Studies, 45(8): 1107-1119.

VOYCE, M. (2006): Shopping Malls in Australia. The End of Public Space and the Rise of Consumerist Citizenship? Journal of Sociology, 42(3): 269-286.

WAKEFIELD, K. L., BAKER, J. (1998): Excitement at the mall: determinants and effects on shopping response. Journal of Retailing, 74(4): 515-539.
WALMSLEY, D. J., LEWIS, G. J. (1984): Human Geography: Behavioural Approaches. London, Longman.

WARNABY, G., BENNISON, D., DAVIES, B. J. (2005): Retailing and the marketing of urban places: a UK perspective. The International Review of Retail, Distribution and Consumer Research, 15(2): 191-215.

WOLF, K. (2003): Retail and Urban Nature: Creating a Consumer Habitat. Population and Environmental Psychology Bulletin, 29(1): 1-6.

\section{Please cite this article as:}

KUNC, J., KRIŽAN, F., BILKOVÁ, K., BARLÍK, P., MARYÁŠ, J. (2016): Are there differences in the attractiveness of shopping centres? Experiences from the Czech and Slovak Republics. Moravian Geographical Reports, 24(1):27-41. Doi: 10.1515/mgr-2016-0003. 